\title{
ARTIKEL
}

\section{PENGARUH MINAT BELAJAR DENGAN HASIL BELAJAR TEKNOLOGI DASAR OTOMOTIF SISWA KELAS X TSM DI SMK NEGERI 1 SINONSAYANG}

\author{
Arlan Hendra Mabel Pangaribuan, Dr. H. M. Sumual, ST, M, Eng, David O. Mapaliey M.Pd \\ Pendidikan Teknik Mesin Fakultas Teknik Univeritas Negeri Manado \\ arlanpangaribuan@gmail.com, hendrosumual@unima.ac.id,daveokta@gmail.com
}

\begin{abstract}
ABSTRAK
Pendidikan merupakan salah satu proses kegiatan pembentukan sikap kepribadian, keterampilan dan meningkatkan potensi diri setiap orang untuk menghadapi masa depan. Pada umumnya sikap kepribadian siswa ditentukan oleh pendidikan, pengalaman, dan latihan-latihan yang dilalui sejak kecil. Keadaan di SMK Negeri 1 Sinonsayang bahwa, minat belajar siswa masih rendah dalam pembelajaran Teknologi dasar otomotif (PDO) terlihat dari aktifitas didalam kelas, kurang antusias dalam belajar dan mengerjakan soal saat diberikan guru, tidak mengerti apa yang akan dipelajari, dan tidak memahami mengapa sesuatu itu perlu dipelajari yang akhirnya kegiatan belajar-mengajar kurang efisien, siswa tidak kondusif pada saat guru menjelaskan. Dengan demikian tujuan yang hendak dicapai dalam penelitian ini yaitu Mengetahui pengaruh minat belajar dengan hasil mengajar teknologi dasar otomotif Siswa Jurusan TSM SMK Negeri 1 Sinonsayang Tahun Pembelajaran 2019/2020. Metode penelitian yang digunakan adalah metode penelitian kualitatif. Dan hasil penelitian: diperoleh hasil Tingkat minat belajar siswa bernilai 4,02 dengan nilai rata-rata perasaan senang 4,23, nilai rata-rata terendah berada pada keterlibatan siswa 3,71. Hal ini menunjukkan bahwa minat belajar siswa di SMK Negeri 1 Sinonsayang dikategorikan baik.
\end{abstract}

\section{“Kata kunci: Pengaruh minat dengan hasil belajar teknologi dasar otomotif}

\begin{abstract}
Education is one of the processes of shaping personality attitudes, skills and improving each person's potential for what lies ahead. A student's personality attitude is generally determined by schooling, experiences, and exercises passed through from infancy. The circumstances in SMK Negeri 1 Sinonsayang are cumulative that students' interest in learning is low in basic automotive technology (pdo) are reflected in activities within the classroom, lack of enthusiasm for learning and working on the problem when given by the teacher, do not understand what to learn, and do not understand why something should be studied which is less efficient. The objective of this study is to see how the interest in learning results from teaching basic automotive technology for TSM SMK Negeri 1 Sinonsayang students of the 2019/2020 school year. The research method used is qualitative research. And research results: obtained results of the level of interest studying students are worth 4.02 with an average value of feeling 4.23 , the lowest average value being on student involvement 3.71. This indicates that the studying interest of students in SMK Negeri1 Sinonsayang is categorized as good.
\end{abstract}

"Keywords: the effects of interest in learning basic automotive technology" 


\section{PENDAHULUAN}

Pembelajaran merupakan proses pembuatan perilaku orang, keahlian, serta kenaikan kemampuan tiap orang buat masa depan. Secara universal, perilaku kepribadian siswa didetetapkan oleh pembelajaran, pengalaman serta latihan yang diterima semenjak umur dini. Bila siswa menampilkan kemampuan tugas serta topik yang besar cocok dengan tujuan serta target pembelajaran, hingga pembelajaran diucap bermutu. Tercapainya tujuan pembelajaran bisa dilihat lewat prestasi akademik siswa.

Dengan menggunakan kemampuan sumber energi yang terdapat, spesialnya untuk siswa bisa digali dalam proses pendidikan. Supaya sukses dalam proses pendidikan, pada dasarnya dipengaruhi oleh aspek sempurna ataupun aspirasional, serta diiringi dengan tingkatan atensi yang besar buat menggapai prestasi. Terus menjadi besar prestasi seorang dalam menggapai apa yang dicita- citakannya, hingga hendak terus menjadi semangat dia bekerja buat menggapai tujuannya. Keberhasilan proses pendidikan sangat dipengaruhi oleh aspek internal. Aspek internal yang dibahas merupakan yang berasal dari siswa ialah kecerdasan, atensi, kemandirian, perilaku serta bakat siswa.

Atensi belajar merupakan derajat intensitas siswa buat belajar, sehingga memastikan tujuan belajar. Mahasiswa ialah generasi penerus bangsa serta diharapkan sanggup membangun negeri ke arah yang lebih baik, ialah lewat semangat ataupun minat belajar yang besar tanpa dituntut ataupun diperintahkan. Mereka yang tidak berminat belajar tidak hendak menggapai tujuan ataupun memperoleh tutorial penerapan, terlebih bila mereka belajar, menggerakkan ataupun membimbing suasana belajar tanpa dorongan sendiri, mereka lebih cenderung memunculkan keletihan ataupun kebosanan. Atensi belajar pula berfungsi dalam keberhasilan aktivitas belajar mengajar yang diberikan. Atensi belajar ialah salah satu tolak ukur buat tingkatkan hasil belajar siswa. Dengan atensi, siswa secara otomatis hendak belajar buat menggapai tujuannya.

Karakteristik siswa yang berminat merupakan mau berpartisipasi dalam sesuatu tugas ataupun aktivitas. Dengan kata lain, orang yang berminat tentu hendak belajar dengan aktif, mengerjakan tugas dengan tekun serta ulet, menampilkan atensi yang kokoh, bekerja secara mandiri, serta tidak hendak gampang membebaskan apa yang dianggapnya benar. atensi serta mau berpartisipasi. Berkaitan dengan perihal tersebut, guru dituntut mempunyai keahlian buat membangkitkan atensi siswa serta membuat mereka aktif belajar ( Sadiman, 2011).

Revisi kurikulum ialah salah satu upaya buat tingkatkan mutu pembelajaran.. Bila pola aktivitas pendidikan berganti, dari berpusat pada guru jadi berpusat pada siswa, serta dari berorientasi pada diskriminasi siswa jadi berorientasi pada penilaian yang membedakan siswa, hingga upaya tersebut sukses. Seluruh pergantian ini hendak memastikan hasil pembelajaran. Ketepatan evaluasi yang dicoba 
oleh sekolah, spesialnya yang berkaitan dengan evaluasi kelas, menampilkan pencapaian hasil belajar siswa. Penilaian pengaruhi tata cara, aktivitas serta sumber belajar yang digunakan guru dalam proses pendidikan.

Kondisi di Sekolah Menengah Kejuruan (SMK) Negara 1 Sinonsayang kalau, motivasi belajar siswa masih rendah dalam pendidikan Teknologi dasar otomotif (PDO) nampak dari kegiatan didalam kelas, Antusiasme belajar serta mengerjakan soal- soal yang dilontarkan guru kurang besar, serta aku tidak paham apa yang hendak aku pelajari, kenapa aku butuh menekuni suatu, yang pada kesimpulannya menimbulkan rendahnya efisiensi aktivitas mengajar. siswa tidak baik buat siswa, serta siswa tidak ataupun tidak menyadari pengajaran. Berartinya aktivitas belajar salah satu di Sekolah Menengah Kejuruan (SMK) Negara 1 Sinonsayang.

Dari periset terdahulu bisa disimpulkan kalau motivasi belajar berhubungan dengan hasil belajar siswa, dengan terdapatnya motivasi hingga aktivitas belajar siswa hendak terus menjadi maksimal. Karena motivasi ialah serangkaian usaha yang mendesak seorang buat melaksanakan suatu dengan baik.

Bersumber pada latar balik diatas, hingga periset tertarik buat mempelajari dengan judul riset selaku berikut: Pengaruh Atensi Belajar Terhadap Hasil Belajar Teknologi Dasar Otomotif Jurusan TSM Sekolah Menengah Kejuruan (SMK) Negara I Sinonsayang.

\section{Identifikasi Masalah}

Minimnya atensi belajar siswa serta pada dikala proses belajar mengajar kurang efektif

Pengertian Minat Belajar

Bagi Muhibbin Syah (2010), secara simpel atensi berarti tingkatan kecenderungan serta kegairahan yang besar ataupun kemauan yang kokoh terhadap suatu. Atensi merupakan kemauan hendak suatu yang mencuat dari kegairahan ataupun atensi yang besar. Indeks Atensi Belajar

\section{Indikator minat belajar}

Bagi Slamento (2010), sebagian penanda atensi belajar merupakan: rasa bahagia, atensi, penerimaan, serta partisipasi siswa.

1) Perasaan senang

Bila siswa mempunyai perasaan yang mengasyikkan terhadap sesuatu kelas tertentu, hingga tidak hendak terdapat perasaan terpaksa buat belajar, semacam bahagia menjajaki kelas, tidak merasa bosan, serta muncul di kelas.

2) Keterlibatan siswa

Partisipasi seorang pada objek membuat orang tersebut bahagia serta tertarik buat melaksanakan ataupun ikut serta dalam kegiatan objek tersebut. Contoh: Aktif berdiskusi, aktif bertanya, serta aktif menanggapi persoalan yang diajukan guru.

3) Ketertarikan

Mempengaruhi dengan energi dorong siswa terhadap ketertarikan pada suatu barang, orang, aktivitas ato bias berbentuk pengalaman afektif yang dirangsang oleh aktivitas itu sendiri. contoh: bersemangat dalam menjajaki pelajaran, tidak menunda tugas dari guru. 
4) Perhatian siswa

Atensi serta atensi ialah 2 perihal yang dikira sama dalam pemakaian tiap hari, atensi siswa ialah konsentrasi siswa terhadap pengamatan serta penafsiran, dengan mengesampingkan yang lain. Siswa mempunyai atensi pada obyek tertentu hingga dengan sendirinya hendak mencermati obyek tersebut. contoh: mencermati uraian guru serta mencatat modul.

\section{Pengertian Hasil Belajar}

Hasil belajar ialah hasil dari sesuatu interaksi tindak belajar serta tindak mengajar. Jadi hasil belajar pada hakikatnya ialah berubahnya sikap partisipan didik meliputi kognitif, afektif, dan psikomotoriknya. Sehingga tiap pendidik nyatanya hendak mengharapkan supaya hasil belajar partisipan didiknya itu bertambah sehabis melaksanakan proses pendidikan.

Bagi Slameto (2010) belajar yakni sesuatu proses usaha yang dicoba seorang buat mendapatkan sesuatu pergantian tingkah laku yang baru secara totalitas, selaku hasil pengalamannya sendiri dalam interaksi dengan lingkungannya.

Belajar ialah komponen ilmu pembelajaran yang berkenaan dengan tujuan serta bahan acuan interaksi, baik yang bertabiat eksplisit ataupun implisit (tersembunyi). Secara universal, belajar boleh dikatakan pula selaku sesuatu proses interaksi antara diri manusia dengan lingkungannya, yang bisa jadi berwujud individu, kenyataan, konsep maupun teori.

Bagi Muhidin Syah (2008) belajar merupakan aktivitas yang berproses serta ialah faktor yang sangat fundamental dalam penyelenggaraan tiap jenjang pembelajaran. Belajar ialah proses dasar dari pertumbuhan hidup manusia, dengan belajar manusia melaksanakan perubahan- perubahan kualitatif orang sehingga tingkah lakunya tumbuh. Seluruh kegiatan serta prestasi hidup manusia tidak lain merupakan hasil dari belajar. Sebab itu belajar berlangsung secara aktif serta integratif dengan memakai bermacam wujud perbuatan buat menggapai sesuatu tujuan. Menimpa penafsiran belajar, dalam Kamus Besar Bahasa Indonesia didapatkan 3 penafsiran selaku berikut:

a) belajar merupakan berupaya mendapatkan keahlian ataupun ilmu

b) belajar merupakan berlatih

c) belajar merupakan berganti tingkah laku ataupun asumsi yang disebabkan oleh pengalaman.

Faktor-Faktor yang Mempengaruhi Hasil Belajar

Tiap aktivitas belajar menciptakan sesuatu pergantian yang khas selaku hasil belajar. Hasil belajar bisa dicapai partisipan didik lewat usaha- usaha selaku pergantian tingkah laku yang meliputi ranah kognitif, afektif serta psikomotorik, sehingga tujuan yang sudah diresmikan tercapai secara maksimal. Hasil belajar yang diperoleh partisipan didik tidak sama 
sebab terdapat sebagian aspek yang pengaruhi keberhasilannya dalam proses belajar.

Bagi Slameto (2003), faktor- faktor yang pengaruhi belajar banyak jenisnya, namun bisa digolongkan jadi 2 golongan ialah aspek intern serta aspek ekstern. Aspek intern merupakan factor yang terdapat dalam diri orang yang lagi belajar, sebaliknya aspek ekstern merupakan aspek yang terdapat di luar orang.

\section{1) Faktor internal, meliputi:}

\section{a) Faktor jasmani}

Yang tercantum ke dalam aspek jasmani ialah aspek kesehatan serta cacat badan.

\section{b) Faktor psikologis}

Sekurang- kurangnya terdapat 7 aspek yang terkategori dalam aspek psikologi yang pengaruhi belajar, ialah: intelegensi, atensi, atensi, bakat, kematangan serta kesiapan.

\section{c) Faktor kelelahan}

Keletihan pada seorang bisa dibedakan jadi 2, ialah keletihan jasmani serta keletihan rohani. Keletihan jasmani nampak dengan lemah lunglainya badan sebaliknya keletihan rohani bisa dilihat dengan terdapatnya kelesuan serta kebosanan sehingga atensi serta dorongan buat menciptakan suatu lenyap.

\section{2) Faktor eksternal, meliputi:}

\section{a) Faktor keluarga}

Siswa yang belajar hendak menerima pengaruh dari keluarga berbentuk metode orang

tua mendidik, kedekatan antara anggota keluarga, atmosfer rumah tangga, kondisi ekonomi keluarga, penafsiran orang tua, serta latar balik kebudayaan.

\section{b) Faktor sekolah}

Aspek sekolah yang pengaruhi belajar ini merupakan mencakup tata cara mengajar, kurikulum, kedekatan guru dengan siswa, kedekatan siswa dengan siswa, disiplin sekolah, perlengkapan pelajaran, waktu sekolah, standar pelajaran diatas dimensi, kondisi gedung, tata cara belajar serta tugas rumah.

\section{c) Faktor masyarakat}

Warga sangat mempengaruhi terhadap belajar siswa. Pengaruh itu terjalin sebab keberadaannya siswa dalam warga. Aspek ini meliputi aktivitas siswa dalam warga, masa media, sahabat berteman, serta wujud kehidupan dalam warga.

Faktor-faktor diatas sangat mempengaruhi terhadap proses belajar mengajar. Kala dalam proses belajar partisipan didik tidak penuhi aspek tersebut dengan baik, hingga perihal tersebut hendak mempengaruhi terhadap hasil belajar yang dicapai oleh partisipan didik. Oleh sebab itu, buat menggapai hasil belajar yang sudah direncanakan, seseorang guru wajib mencermati faktor- faktor diatas supaya hasil belajar yang dicapai partisipan didik dapat optimal.

\section{Kerangka Berpikir}


Bersumber pada latar balik serta landasan teori yang sudah dikemukakan tadinya, hingga riset ini bisa ditafsirkan dalam suatu kerangka berpikir. Kerangka berfikir ini dimaksudkan buat menggambarkan dengan jelas alur pemikiran periset yang berkaitan dengan pengaruh minat belajar terhadap hasil belajar siswa pada mata pelajaran Teknologi Dasar Otomotif di SMK Negeri 1 Sinonsayang.

Minat ialah dasar yang sangat berarti dalam keberhasilan proses pendidikan. Bila siswa merasa bahagia dalam belajar, hingga hendak dengan kilat paham serta menguasai modul yang diberikan guru. Sebab atensi merupakan kecenderungan yang senantiasa buat mencermati serta memegang sebagian aktivitas. Bila aktivitas yang diminati seorang itu hendak dicermati terus menerus yang diiringi perasaan bahagia, hingga dia bisa meningkatkan atensi pada suatu yang pada dasarnya menolong siswa memandang gimana pengaruh modul yang diharapkan bisa dipelajarinya dengan dirinya sendiri (orang). Proses ini membuktikan kepada siswa gimana pengetahuan atas kecakapan tertentu pengaruhi dirinya, melayani tujuan- tujuannya, serta memuaskan kebutuhan- kebutuhannya. Atensi tidak dibawa semenjak lahir, melainkan diperoleh setelah itu. Begitu pula halnya dengan atensi siswa dalam menjajaki pelajaran pada mata pelajaran Teknologi Dasar Otomotif, dia tidak hendak mencuat tanpa terdapat pengaruh dari luar dirinya.

\section{METODOLOGI PENELITIAN}

\section{Desain Penelitian}

Riset ini memakai tata cara riset kuantitatif, yang digunakan buat mempelajari pada populasi ataupun ilustrasi tertentu.

\section{Tempat Dan Waktu Penelitian}

Penelitian dilakukan di SMK Negeri 1 Sinonsayang di desa Poigar Kec. Sinonsayang Kab. Minahasa Selatan dengan waktu penelitian bulan april 2021

\section{Populasi Dan Sampel Penelitian}

Populasi siswa di SMK Negeri 1 Sinonsayang dengan jumlah 30 siswa dan sampel berdasarkan penelitian berjumlah 30 siswa.

\section{Defenisi Operasional Variabel}

Variabel Independent (x) Minat Belajar

Minat Belajar Belajar merupakan rasa lebih suka serta rasa ketertarikan pada sesuatu perihal ataupun kegiatan, tanpa terdapat yang menyuruh. Minat pada dasarnya merupakan penerimaan hendak sesuatu pengaruh antara diri sendiri dengan suatu diluar dirinya. Minat bisa pula dimaksud selaku energi penggerak di dalam diri siswa yang memunculkan, menjamin kelangsungan serta membagikan arah aktivitas belajar, sehingga diharapkan tujuan bisa tercapai, ialah memperoleh hasil yang memuaskan.

variabel dependent (y) Hasil Belajar

Diambil dari hasil belajar ujian tengah semester siswa, pada mata pelajaran 
Teknologi Dasar Otomotif Pada siswa kelas X Program keahlian Teknologi Sepeda Motor, semester ganjil tahun ajaran 2020/2021.

\section{Teknik Pengumpulan Data}

\section{Dokumentasi}

Analisis dokumen yang dicoba buat mengumpulkan informasi yang bersumber dari arsip serta dokumen baik yang terletak di sekolah ataupunyang terletak diluar sekolah, yang terdapat pengaruh riset tersebut. Riset dokumentasi ialah Teknologi pengumpulan informasi dengan menghimpun serta menganalisis dokumen- dokumen, baik dokumen tertulis, foto, ataupun tidak tertulis (sukmadinakta, 2007). Dokumentasi dalam riset ini digunakan buat mengumpulkan informasi tetang hasil belajar mata pelajaran Teknologi dasar otomotif kelas X TSM. Informasi buat variabel hasil belajar mengunakan hasil tes semester genap tahun ajaran 2019/2020 sebab tes akhir ini masih berbentuk nilai murni tanpa di tambah dengan nilai lainya.

\section{Angket}

Angket ialah tata cara pengumpulan informasi yang di pengumpulan dengan metode mengunakan persoalan yang wajib di kerjakan ataupun di jawab oleh orang yang meliputi target angket tersebut. Dalam riset ini, angket yang digunakan mengumpulkan informasi tentang atensi belajar. Instrument riset ini merupakan perlengkapan ataupun sarana yang digunakan periset dalam mengumpulkan informasi supaya
Teknologinya lebih gampang serta hasilnya lebih baik ialah:

Tata cara kuesioner ialah Teknologi pengumpulan informasi yang dicoba dengan metode berikan sebagian persoalan kepada responden buat dijawab. Kuesioner ini terdiri dari butir- butir persoalan menimpa Atensi Belajar. Kuesioner tentang Atensi Belajar, ditinjau dari jawaban yang diberikan tercantum kuesioner langsung sebab responden menanggapi tentang dirinya (Arikunto, 2013).

\section{Instrumen Penelitian}

Instrumen penelitian merupakan alat bantu yang digunakan untuk mengukur data yang berhubungan dengan variabel penelitian.

\section{A. Uji Hipotesis}

Ada pengaruh minat belajar terhadap hasil belajar teknologi dasar otomotif kelas X TSM di SMK Negeri 1 Sinonsayang.

\section{Hasil Penelitian dan Pembahasan}

\section{Hasil penelitian minat}

Pada indicator perasaan bahagia bisa dilihat kalau sebagian besar menanggapi sangat sepakat ialah $38 \%$, yang menanggapi sepakat 50,66\%, yang menanggapi ragu- ragu $8,7 \%$, yang menanggapi kurang sepakat 1,98\%, serta yang menanggapi tidak sepakat $0,66 \%$. Cocok dengan penanda dengan nilai 4,23 dikategorikan baik. Dari uraian diatas bisa dilihat diagram bundaran selaku berikut: 


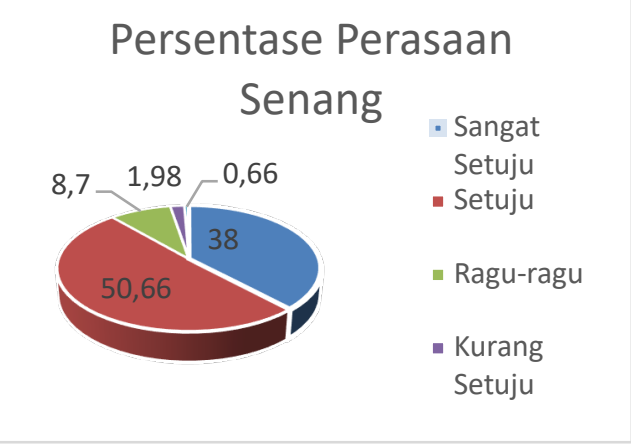

Pada indicator keterlibatan siswa bisa dilihat kalau sebagian besar menanggapi sangat sepakat ialah 23,32\%, yang menanggapi sepakat $37,32 \%$, yang menanggapi ragu- ragu $28,68 \%$, yang menanggapi kurang sepakat $8,66 \%$, serta yang menanggapi tidak sepakat 1,98\%. Cocok dengan penanda dengan nilai 3,71 dikategorikan baik. Dari uraian diatas bisa dilihat diagram bundaran selaku berikut:

\section{Persentase Keterlibatan Siswa}

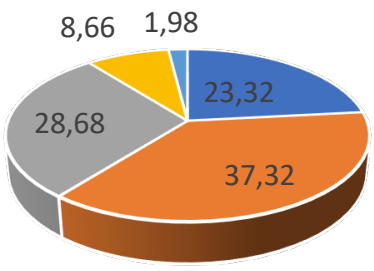

$$
\begin{aligned}
& \text { - Sangat setuju } \\
& \text { - Setuju } \\
& \text { - Ragu-ragu } \\
& \text { - Kurang Setuju } \\
& \text { - Tidak Setuju }
\end{aligned}
$$

Pada indicator ketertarikan siswa bisa dilihat kalau sebagian besar menanggapi sangat sepakat ialah 25,34\%, yang menanggapi sepakat $49,34 \%$, yang menanggapi ragu- ragu $14,66 \%$, yang menanggapi kurang sepakat 7,34\%, serta yang menanggapi tidak sepakat 3,32\%. Cocok dengan indicator dengan nilai 3,86 dikategorikan baik. Dari uraian diatas bisa dilihat diagram bundaran selaku berikut:

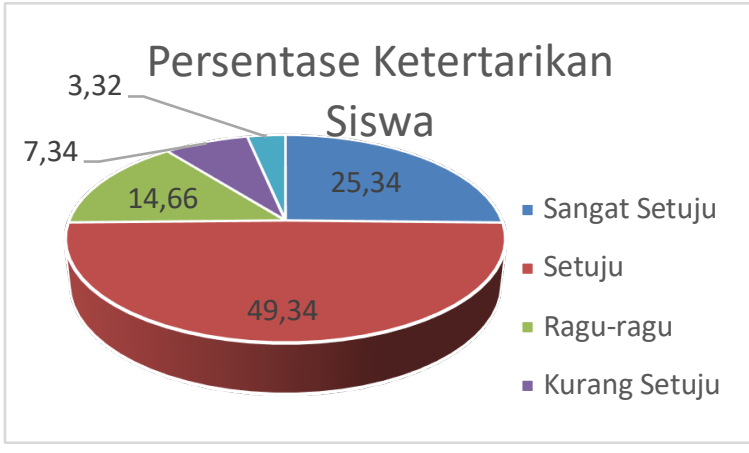

bisa dilihat kalau sebagian besar menanggapi sangat sepakat ialah $37,34 \%$, yang menanggapi sepakat 48\%, yang menanggapi ragu- ragu 13,98\%, yang menanggapi kurang sepakat $0,66 \%$. Cocok dengan penanda dengan nilai 4,21 dikategorikan baik. Dari uraian diatas bisa dilihat diagram bundaran selaku berikut;

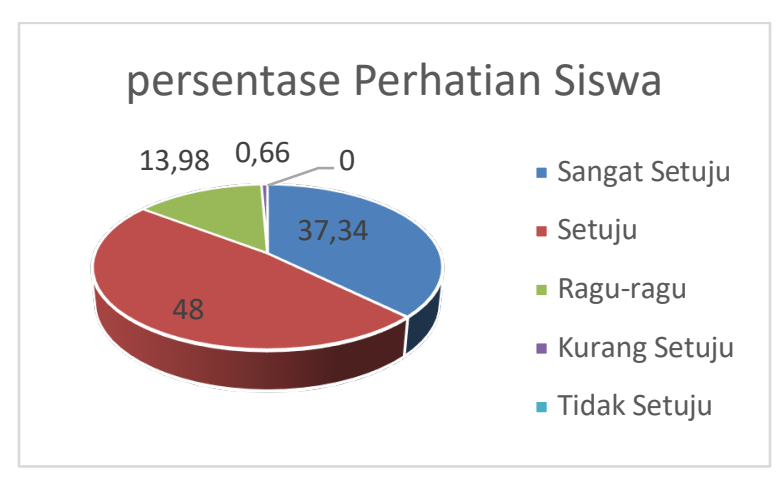

\begin{tabular}{|l|l|l|l|}
\hline Butir & \multicolumn{1}{|c|}{ INDIKATOR } & $\begin{array}{c}\text { RATA- } \\
\text { RATA }\end{array}$ & KATEGORI \\
\hline 1 & Perasaan senang & 4,23 & Baik \\
\hline 2 & $\begin{array}{l}\text { Keterlibatan } \\
\text { Siswa }\end{array}$ & 3,71 & Baik \\
\hline 3 & $\begin{array}{l}\text { Ketertarikan } \\
\text { Siswa }\end{array}$ & 3,86 & Baik \\
\hline 4 & Perhatian Siswa & 4,21 & Baik \\
\hline \multicolumn{2}{|l}{ RATA-RATA } & 4,02 & Baik \\
\hline
\end{tabular}


Cocok dengan bisa dikenal kalau tingkatan Atensi belajar siswa bernilai 4,02 dengan nilai rata- rata paling tinggi menunjuk pada ulet serta tidak putus asa dalam belajar sebesar 4,23. Nilai rata- rata terendah terletak pada tekun dalam mengalami tugas, sebesar 3,71. Perihal ini menampilkan kalau Minat belajar siswa di SMK Negeri 1 Sinonsayang dikategorikan baik.

\section{Hasil Belajar TDO}

Berdasarkan data yang diperoleh dari penelitian tentang hasil belajar siswa yang diperoleh dari Ujian Akhir Sekolah kelas X TSM SMK Negeri 1 Sinonsayang pada mata pelajaran TDO, nilai tertinggi 80 dan nilai terendah 70 dengan KKM untuk pelajaran TDO 75

\begin{tabular}{|c|c|c|c|}
\hline No & $\begin{array}{l}\text { Interval } \\
\text { Frekuensi }\end{array}$ & $\begin{array}{l}\text { Frekuens } \\
\text { i }\end{array}$ & $\begin{array}{l}\text { Frekuensi } \\
\text { Relatif \% }\end{array}$ \\
\hline 1 & $70-75$ & 26 & 86,6 \\
\hline 2 & $76-81$ & 4 & 13,4 \\
\hline \multicolumn{2}{|c|}{ Jumlah } & 30 & 100 \\
\hline
\end{tabular}

\section{Pembahasan}

Mengenai minat belajar TDO siswa $\begin{array}{llllll}\text { kelas } & \mathrm{X} & \mathrm{TSM} & \mathrm{SMK} & \text { Negeri } 1\end{array}$ SINONSAYANG, diperoleh hasil bahwa tingkat minat belajar siswa bernilai 4,02 Dengan nilai rata-rata tertinggi berada pada menunjukkan 4,23, nilai rata-rata terendah berada pada tekun dalam menghadapi tugas 3,71 , hal ini menujukkan bahwa minat belajar siswa di SMK Negeri 1 SINONSAYANG dikategorikan baik.

Kofesien korelasi dihitung menunjukkan besarnya Pengaruh itu adalah $\mathbf{r}_{\text {hitung }}=0,746$ Yang dikategorikan korelasi sempurna. kuatnya Pengaruh antara minat belajar dengan hasil belajar TDO siswa adalah $73,1 \%$, hal ini memberikan gambaran bahwa ada sebesar $73,1 \%$ variasi belajar TDO yang dapat dijelaskan oleh minat belajar, sedangkan sisahnya $26,9 \%$ ditentukan oleh factor lain, misalnya faktor eksternal seperti lingkungan belajar, lingkungan masyarakat, lingkungan sosial budaya, ssarana dan prasarana lainya (Hamdayani.2010)

Dari hasil analisis data diketahui bahwa terdapat Pengaruh antara minat belajar dengan hasil belajar TDO siswa. Hal ini dapat dilihat dari hasil uji $\mathrm{t}$ diperoleh $\mathrm{t}_{\text {hitung }}>\mathrm{t}_{\text {tabel }}$ $2.847>2.051$

Jadi hipotesis dalam penelitan ini yakni terdapat Pengaruh yang signifikan antara minat belajar dengan hasil belajar TDO siswa $\begin{array}{llllll}\text { kelas } & \mathrm{X} & \mathrm{TSM} & \mathrm{SMK} & \text { NEGERI }\end{array}$ SINONSAYANG. Dapat diterima atau dengan kata lain Pengaruh signifikan antara minat belajar dengan hasil belajar TDO kelas X TSM SMK NEGERI I SINONSAYANG. 


\section{Kesimpulan}

Minat belajar berpengaruh secara positif dan signifikan dengan hasil belajar TDO dengan koefisien korelasi 0,746, maka diperoleh nilai $\mathrm{T}_{\text {hitung }}>\mathrm{T}_{\text {tabel }}(2.847>2.051)$, pada taraf signifikan 0,05. Kuatnya Pengaruh antara minat belajar terhadap hasil belajar TDO siswa adalah 73,1\%. Hal ini memberikan gambaran sebesar bahwa minat belajar ada sebesar $73,1 \%$, variasi hasil belajar TDO yang dapat dijelaskan oleh minat belajar, sedangkan $26,9 \%$ ditentukan oleh factor lain. Contoh pengaruh lingkungan masyarakat, sosial budaya dll.

\section{DAFTAR PUSTAKA}

Muhibbin Syah,Psikologi Pendidikan, Bandung, PT Remaja Rosdakarya, 2008

Sukmadinata, Nana Syaodih. 2007. Metode Penelitian: Pendidikan. Bandung: Rosdakarya.

Sugiyono. 2010. Metode Penelitian Pendidikan Pendekatan

Kuantitatif, kualitatif, dan R\&D. Bandung: Alfabeta

Sugiyono. 2011. Metode Penelitian

Pendidikan Pendekatan

Kuantitatif, kualitatif, dan

R\&D. Bandung: Alfabeta 